\title{
Learning Innovation of Qibla Direction with Mobile-Based App by Adapting Computational Thinking
}

\author{
Fajar Fathurahman \\ Universitas Islam Jakarta, Indonesia
}

fajar.fathurahman@gmail.com

\begin{tabular}{|c|c|}
\hline \multirow{3}{*}{$\begin{array}{l}\text { ARTICLE INFO } \\
\text { Article history: } \\
\text { Received } \\
\text { July 21, } 2020 \\
\text { Revised } \\
\text { May 05, 2021 } \\
\text { Accepted } \\
\text { May 17, } 2021\end{array}$} & ABSTRACT \\
\hline & $\begin{array}{l}\text { This research was conducted to obtain the results of the development of } \\
\text { Learning to Determine Qibla Direction with Computational Thinking } \\
\text { Adaptation using Mobile-Based Applications. The researcher used mixed } \\
\text { methods with a sequential exploratory research design that takes two } \\
\text { stages (qualitative-quantitative). The R \& D stage used } 5 \text { (five) steps of the } \\
\text { ADDIE method, namely Analysis, Design, Development, Implementation } \\
\text { and Evaluation. This research was conducted at the office of the Ministry } \\
\text { of Religion of the Thousand Islands Regency, with the result that the } \\
\text { learning innovations carried out were appropriate and met expectations. } \\
\text { The learning process for training participants and in practice its } \\
\text { application was easier and more affordable. The Qibla direction training } \\
\text { used in this mobile-based application was applied with a learning pattern } \\
\text { that adapts computational thinking skills, which were arranged in four } \\
\text { phases, namely: Elaboration, Determination, Calculation, and Evaluation. } \\
\text { This learning innovation shows that it can improve participants' } \\
\text { understanding of the concept of calculating Qibla Direction which was } \\
\text { applied integratively between religion, science and technology as a } \\
\text { coherent knowledge. }\end{array}$ \\
\hline & $\begin{array}{l}\text { Keywords: Mobile-Based App, Learning Innovation, Adapting Computational } \\
\text { Thinking }\end{array}$ \\
\hline ow to cite & $\begin{array}{l}\text { Fathurahman, F., (2021). Learning Innovation of Qibla Direction with Mobile- } \\
\text { based App by Adapting Computational Thinking. Jurnal Iqra': Kajian Ilmu } \\
\text { Pendidikan, 6(1). 211-224. https://doi.org/10.25217/ji.v6i1.981 } \\
\text { http.//iournal iaimnumetrolampung acid/index php/ii/ }\end{array}$ \\
\hline urnal Homepage & $\begin{array}{l}\text { http://journal.iaimnumetrolampung. } \\
\text { cle under the CC BY SA license } \\
\text { https://creativecommons.org/license }\end{array}$ \\
\hline
\end{tabular}

\section{INTRODUCTION}

The Thousand Islands Regency geographically it is located north of Jakarta Bay between $106^{\circ} 19^{\prime} 30^{\prime \prime}-106^{\circ} 44^{\prime} 50^{\prime \prime}$ East Longitude and $5^{\circ} 10^{\prime} 00$ "- 5 $5^{\circ}$ 57 00" South Latitude. An area of the Thousand Islands Regency which is part of the Jakarta Capital Region Province consisting ocean with a total area of $4,745.62 \mathrm{~km} 2$ and of $8.76 \mathrm{~km} 2$ of island land inhabited by the population, the rest of which are sea islands of sand and coral reefs.

The poppulation of Thousand Islands Regency is 100\% Muslim, whose demographic conditions are separated by the sea on 17 islands. In all inhabited islands there are mosques and prayer rooms. Constraints that exist today are still many mosques, prayer rooms and homestay worship facilities owned by Muslims who had not received qibla direction determination sertification services for the local ministry of religion, The specific problem is the limitations faced by the local ministry of religion, These constraints can be grouped into factors as follows: 1)A lack of human resource 
and the absence of officers who are able to provide qibla direction determination sertification services. 2)There is no innovative training that can be carried out to prepare local human resources to carry out Qibla direction services that are effective, affordable and easy for the community. 3)Ocean geographic conditions that limit the affordability of access and the risks of sea transportation in reaching services. 4) The demographic condition of the archipelago with a population that is spread beyond the limit of service coverage.

By looking at the geographical and demographic conditions within the Ministry of Religion Thousand Islands Regency, Then the implementation of Qibla direction training services in this archipelago could not be done conventionally as is usually carried out on land. Qibla direction training services in this area needs to pay attention to geographical and demographic factors that are restricted to ocean areas as described above.

In order to realize effective and efficient Qibla direction guidance training services in the Ministry of Religion Office of Thousand Islands Regency, it is necessary to develop a mobile application for Qibla direction guidance service. The developed application is intended to be easily accessible whenever and wherever it is so that geographical and demographical limitations can be overcome. Therefore, this research of the R \& D type needs to be carried out to solve the problems faced above. The difference in this research from the previous study is that it intends to initiate innovative Qibla direction training learning that adapts computational thinking skills with the support of mobile-based applications that are suitable for application in instant technical training for employees at the local Ministry of Religion.

The deviation of the Qibla direction in the Thousand Islands district varies, but the measurement results of several mosques in the preliminary study are more than 3 degrees. If converted to a distance of 3 degrees, you will find the deviation of the Qibla direction from the Kaaba to the mosque at a range of 452.3 kilometers. Mulyadi, (2013) Suggested that the most important thing that the Ministry of Religion must do in minimizing the problem of Qibla direction in the community is to provide a certificate of Qibla Direction to mosques or mushalla that have certified the Qibla direction. Thus the community is expected to feel comfortable in carrying out worship (Ulum, 2020). This certainly cannot be achieved if the staff of the local ministry of religion do not yet have the competency in question.

Considering that the participants of the Qibla direction training in the Thousand Islands are parents aged 35-45 years, it is necessary to look back at how the pedagogical approach to learning the Qibla direction measurement at the elementary school level. There needs to be a concept of ease of teaching so that the material presented by the trainer is absorbed. Through mathematics subjects on angle measurement material can be done by the teacher starting with an explanation of the procedures for measuring angles using a bow ruler, then continued with angle measurement exercises, providing worksheets on measuring the Qibla direction, finally making conclusions about the direction of the Qibla, proven to improve participant understanding easily (Solikin, 2017).

To make this happen, the first step taken was to develop a mobile-based Qibla direction application. The mobile-based application developed is intended to be easily accessible anytime and anywhere, so that geographic and demographic limitations in the archipelago can be overcome. The application is then applied in training that adapts computational thinking skills. This step is to realize the internalization of 
knowledge about the direction of the Qibla by employees of the Ministry of Religion of the Thousand Islands.

An up to date Qibla direction training innovation is needed. While this is often used old methods or conventional teaching techniques (lectures), so that students often experience boredom, even feel tired quickly in participating in the training delivered and decrease the attractiveness of participants to the training material. This condition becomes an obstacle for participants in understanding the material presented so that it becomes difficult to capture knowledge and cannot master the skills of measuring the Qibla direction. Therefore, this $R \& D$ research needs to be carried out to solve the problem of the quality of the Qibla direction training in this working area.

The learning model is intended to increase the sensitivity of training participants to the application of information technology that guides structured thinking, so as to spur a person's problem-solving abilities quickly and precisely, as well as improve their performance and productivity in a measured and directed manner in order to deal with the Qibla direction problem situation that can come at any time the middle of society. The implementation of mobile-based applications in R\&D is specifically designed so that it can function as a learning assistant both physically and virtually, developed to effectively encourage creativity, critical, communicative and collaborative thinking as competencies that the nation's generation needs to master in facing the challenges of the times and progress. digital era in the future. so that it opens access to learning that can be done anytime and anywhere.

\section{METHODS}

The methodology applied in this research is mixed methods with a sequential exploratory research design that takes two steps (qualitative-quantitative). Popular applications in qualitative-quantitative design are exploring phenomena, identifying themes, designing an instrument, and then testing them. This qualitative initial stage focuses on $\mathrm{R} \& \mathrm{D}$ by referring to the 5 steps of the ADDIE model with the aim of producing a web-based mobile learning application that is suitable for the computational thinking learning model that will be applied.

In addition to drawing conclusions in qualitative analysis, hypothesis testing was also carried out in the analysis of the two-way ANOVA multivariate inferential statistical data on the test instrument to analyze the collected pretest and posttest results.

The following is a summary of the ADDIE model steps applied in this study:

1. Analysis Stage: This is the pre-planning phase: studying and deepening thoughts about new products (models and instructional media) that will be developed. Identifying products that are in accordance with the goals of students, learning objectives, identifying learning content / materials, identifying learning environments, and delivery strategies in learning.

2. Design Stage: Designing new product concepts. Designing devices new product development. The design is written on a learning development work paper. Instructions for implementing the design or steps for making the product are written in detail on the storyboard sheet.

3. Development Stage: Develop a product set (materials / materials and tools) which required in development. Based on the design results products, at this stage the product starts to be made (material / tool) according to the structure of the model. In this step, an instrument is also made to measure product performance. 
4. Implementation Stage is the phase in starting to use a new product in a real learning or environment (which is applied in a training / technical guidance). Referring and re-checking product development goals, interactions between students, and asking for feedback early in the evaluation process.

5. Evaluation Stage: Looking back at the impact of learning that has been carried out in a critical and measurable way. Measure the achievement of product development goals. Measure how learning objectives are achieved. Looking for things that can enable the trainees to achieve good training results.

The data collection technique is done by: documentation, interview, observation, and test implementation. Data were collected using two types of instruments, namely tests and non-tests. Data collection is not a test, namely observation, documentation, and interviews. Data collection by test is the implementation of pre-test and post-test.

Before the instrument is used for data collection, it is tested for validity and reliability. Theoretical validity is carried out by experts and empirical validity is carried out by testing validity and reliability. The initial instrument validity test with a nominal measurement scale in the form of a dichotomy score was analyzed using the biserial point correlation technique. Instrument reliability test with a nominal scale using the Kruder Richardson-20.

Qualitative data were analyzed using triangulation techniques and quantitative data were analyzed using descriptive and inferential statistics. Descriptive analysis consists of the mean score of instrument validation, maximum and minimum scores and standard deviation. Inferential statistics are aimed at estimating parameters or variable values in the population (generalization) through the process of testing statistical hypotheses against the sample data. This inductive statistics needs to be done because it uses sample data as a source of information, because if this research only stops at descriptive statistics, the resulting conclusions only apply to the sample, not the population.

The format of inductive statistical data analysis in this study was carried out using a multivariate two-way ANOVA on the pretest and posttest results, to analyze the results of the Qibla direction training participants using its web-based application. Besides that, the activity of analyzing the development result data on the effectiveness and feasibility of using the mobile-based application is by summarizing the data from the instruments that have been collected into a table to be analyzed, then looking for the results of calculating the average value of each measurement aspect of the instrument with the following formula:

Information:

$$
x=\frac{\sum x}{N}
$$

$x=$ Average score of each aspect

$\sum x=$ Total Score

$N=$ Number of validators

The average score is transformed into a qualitative value in accordance with the criteria specified in the following table: 
Table 1. Assessment criteria

\begin{tabular}{|c|c|}
\hline Score Interval & Criteria \\
\hline $\boldsymbol{x}>M i+1.5(S D i)$ & Very Feasible \\
$M i<\boldsymbol{x}<M i+1.5(S D i)$ & Feasible \\
$M i-1.5(S D i)<\boldsymbol{x}<M i$ & Less Feasible \\
$\boldsymbol{x}<M i-1.5(S D i)$ & Not Feasible \\
\hline
\end{tabular}

Information:

Mi (Median Rating Score $)=1 / 2 \times($ Max Score + Min Score $)$

SDi (Standard Deviation Rating Score) $=1 / 2 \times 1 / 3 \times$ (Max Score - Min Score)

Inferential analysis consists of an $\mathrm{N}$-gain normality test to test the improvement in the results of guidance in determining the Qibla direction of trainees. Thus, the application developed can be said to be effective, based on the average participant mostly having a minimum N-Gain value in the medium category, which is formulated as follows:

Information:

$$
N-\text { Gain }=\frac{\text { Posttest Score }- \text { Pretest Score }}{\text { SMI }- \text { Pretest Score }}
$$

SMI = Ideal Maximum Score

With the criteria for the value of $N$ - Gain as in the following table:

Table 2. Criteria for the value of N - Gain

\begin{tabular}{|c|c|}
\hline Criteria Limits of N-Gain Values & Criteria \\
\hline$N-$ Gain $\geq 0.70$ & High \\
$0.30<N-$ Gain $<0.70$ & Middle \\
$N-$ Gain $\leq 0.30$ & Low \\
\hline
\end{tabular}

Table 3. Effectiveness of N - Gain Value

\begin{tabular}{|c|c|}
\hline Effective Limits of N - Gain Value & Criteria \\
\hline$>0.76$ & Very Effective \\
$0.56-0.75$ & Effective \\
$0.40-0.55$ & Less Effective \\
$<0.40$ & Not Effective \\
\hline
\end{tabular}

\section{RESULT AND DISCUSSION}

Computational Thinking is a problem-solving method by applying the patterns used by a software engineer / computer expert in writing programs. so it can be understood that this is the ability to think by solving real-world problems like a computer scientist / software engineer.

Computational Thinking is very important to be applied in today's learning, in order to prepare a generation that is competitive in the digital era. With these skills the training participants will be taught how to learn by following a pattern of thinking how a computer scientist thinks to solve a problem.

At first, the term Computational Thinking was echoed by Seymour Papert (1980) in his book entitled "Mindstorm". that what is meant by computational thinking does not mean thinking like a computer, but rather computational thinking where 
someone is required to formulate existing problems in the form of computational problems and solve them by compiling good computational steps (for example in the form of logical flow patterns or algorithms).

There are several methods of computational thinking, including:

a. Decomposition: Breaking down the problem into smaller ones to the point of the problem, so that the problem can be identified in each section how the problem is described and solved.

b. Pattern Recognition: Recognizing a certain pattern that exists in a problem so that it can be understood from the pattern how the existing problem can be described and solved.

c. Abstraction: Identify problems with generalizations based on general principles that produce patterns, trends and regularities to solve existing problems.

d. Algorithm: Develop a step-by-step problem-solving flow, so that these steps can solve existing problems.

The concept of computational thinking ability is then initiated on how it is applied in learning training about the Qibla direction, which will be included in the process of developing mobile-based learning applications. The stages of developing a mobile-based Qibla direction learning application as a medium / learning material that will be applied in Qibla direction training in accordance with the ADDIE development steps can be explained as follows:

\section{Analisys Stage}

At this stage, the researcher re-analyzes what problems are behind the development of this educational media. After analyzing the problem, the researcher needs to analyze the feasibility and requirements of the mobile-based application to be made.

Researchers will also prepare application design materials in accordance with the conditions of training participants in the office environment of the Ministry of Religion, Thousand Islands District. Then determine how the suitability of the mobile-based application to be developed is in accordance with the learning objectives of the Qibla direction training, identify what teaching materials / materials will be made in the application and prepare the needs for structuring / writing / placement structures in the mobile application to be developed.

\section{Design Stage}

At this stage the researcher will realize what has been explored in the analysis stage, and its relationship with the characteristics of the training participants. Next compile it into a design. The description of the activities in this stage is as follows:

a. Preparing a map of the needs for mobile-based application development.

b. Determining the content, menus and features to be included in the mobile-based application, based on basic competencies, indicators and Qibla direction material, which are also adjusted to the application navigation structure, the rules for exposition of linguistic text and the layout of application content.

c. Writing a design draft is done by formulating the basic competencies that must be mastered by the training participants, the display form and navigation of the applications that will be accessed by the training participants.

d. Making the overall design in the form of a storyboard and compile the application content to be made. 
After the storyboard sheet and draft application content are made, the results are discussed with the programmer to be evaluated and revised so as to produce a good design to be applied in the development process.

\section{Development Stage}

At this stage, the mobile-based Qibla direction application will begin to be developed by researchers according to the predetermined design, after the initial application is successfully made it will be validated by material experts and media experts. If the application made has not reached the positive criteria, the researcher will continue to revise it according to the advice of media experts and material experts. After the application is said to be positive, the researcher will try it out.

At this stage the development process is carried out based on the flow chart and storyboard of the results of designing a mobile-based Qibla direction application. In the development stage, application testing is carried out to see whether the application is valid and feasible or not. This assessment is carried out by material expert validators who are echelon IV officials who master astronomy and astronomy, echelon III officials in charge of Islamic affairs and astronomy and a team of measuring Qibla direction at the Regional Office of the Ministry of Religion of DKI Jakarta Province. The media expert validators are IT experts from RSCM, Mr. Sujiyanto, S.Kom and from the National Library Consultant of the Republic of Indonesia, namely Mr. Deni Syahreza, S.Kom (who is a software engineering and network analyst at each agency).

After the test results are obtained, they are evaluated to revise the application so as to produce a mobile application that has the validity and feasibility of learning media according to targets and expectations, according to the design and needs analysis. After Product Draft I is made to determine its quality as a good learning medium, validation is required by mobile application experts and material experts in the form of responses, suggestions and comments. The results of the validation are then evaluated and analyzed for revision so as to produce Draft Product II until the validator states that it is valid and suitable for limited trials.

Based on the results of the analysis and in accordance with the conclusion of the validation results from the three validators, it shows that the product draft that has been made is declared valid and suitable for use with revisions in accordance with the suggestions and comments that have been submitted. and then applied to Draft II Products. In addition, the analysis of the results of the content validation of the three validators related to the test instruments that will be used to measure the results of the training is declared valid and can be used without revision. 
The following is a screenshot of the mobile-based Qibla direction application that has been successfully developed, which is accessed with an Android phone:

Figure 1. Screenshot of Qibla Learning Mobile App by Computational Thinking Skill
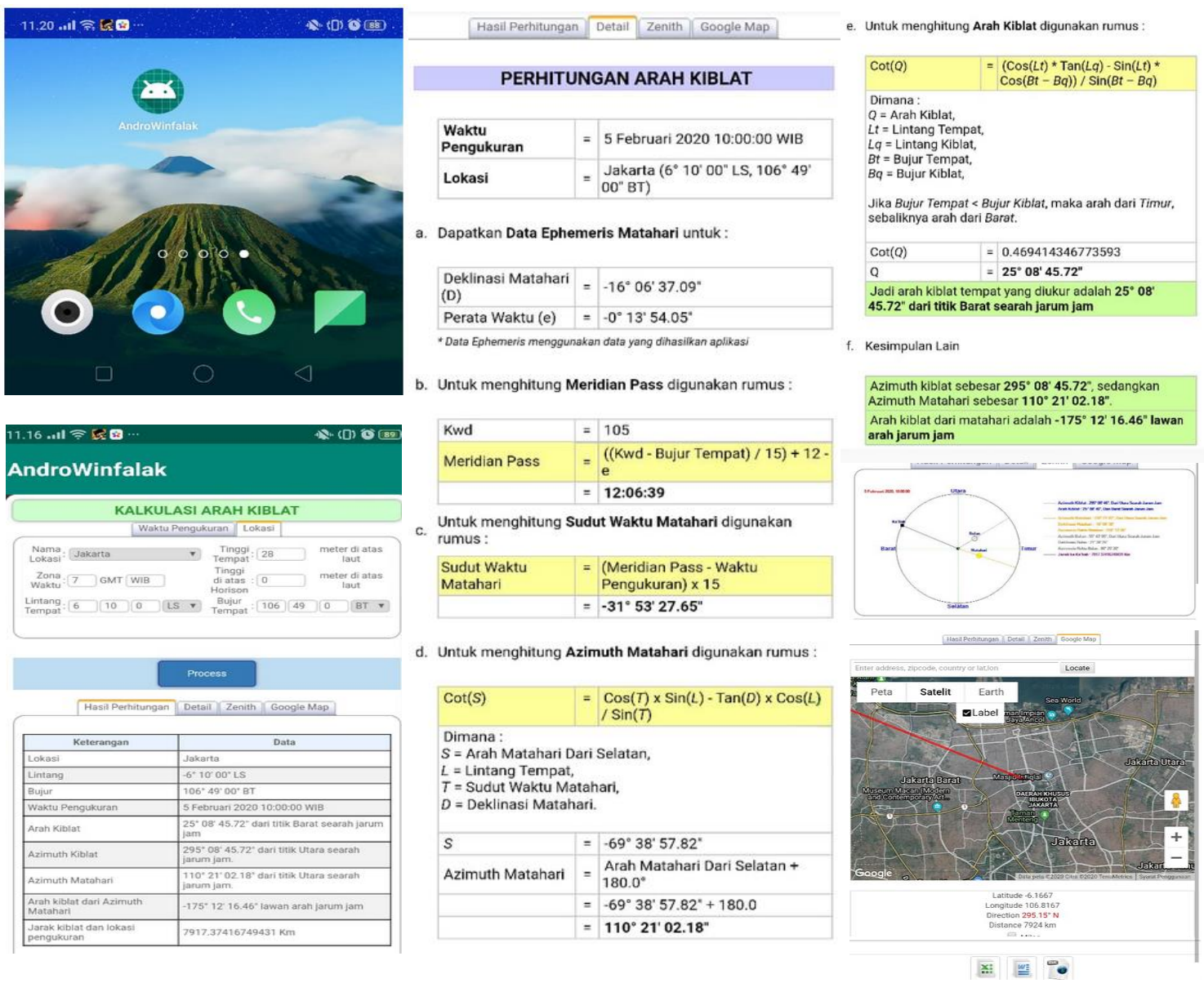

4. Implementation Stage

At this stage the application of the Draft Product II and Test Instruments application that has been made will be carried out for the Qibla direction training participants in the office of the Ministry of Religion, Thousand Islands district.

The mobile-based Qibla direction application and test instruments that have been developed will be applied in real situations, namely in the class of the participants in the Qibla direction. During its implementation, applications that have been developed will be applied in learning patterns that adapt computational thinking skills. The material presented is in accordance with the application content that has been developed.

The results of the development of the Draft Product II application and Test Instruments that were made before being tested on training participants were also carried out by an assessment of validity by echelon III officials, the Head of Islamic Affairs at the Regional Office of the Ministry of Religion of DKI Jakarta Province, also by the Section Head in charge of and 1 (one) a member of the Qibla direction measuring team at the DKI Jakarta Province level.

This Draft Product II application is also used in the simulation of measuring the Qibla direction at 6 locations of mosques and prayer rooms in the DKI Jakarta Province. Some suggestions, comments and input from the results of the validation 
trial are used to improve product quality so that the resulting product meets expectations and is suitable to be applied in innovative learning in Qibla direction training in the Thousand Islands environment.

The Qibla direction training was held on Pramuka Island, attended by 14 people, 5 each from the sub-district KUA delegation and 4 from the Regency Office of the Ministry of Religion. Before the learning process, each participant was tested with a pre-test instrument. The training for Qibla direction guidance services based on mobile applications was carried out for three days with a total of 24 hours of lessons which ended with the implementation of the post test.

\section{Evaluation Stage}

Evaluation is carried out in the form of a formative evaluation carried out by pre-test and post-test. To find out the achievement of the Qibla direction training participants with a mobile-based application that adapts these computational thinking skills, this is done through a comparative analysis of the results of the pre-test and post-test, with a test instrument in the form of multiple choice questions.

The results of the evaluation are used to provide feedback in order to get the results of developing mobile applications that are suitable for the purpose. improvements are made in accordance with the results of the evaluation or the needs that have not been met in training with innovative learning that adapts computational thinking skills. Based on the results of the post test, 6 participants got a score of 10 (100\% correct answers) with an average score of 14 participants being 9.21. The following is an overview of the comparison of the pre-test and post-test results of the training that has been carried out:

Figure 2. Pre-test and Post-test Results

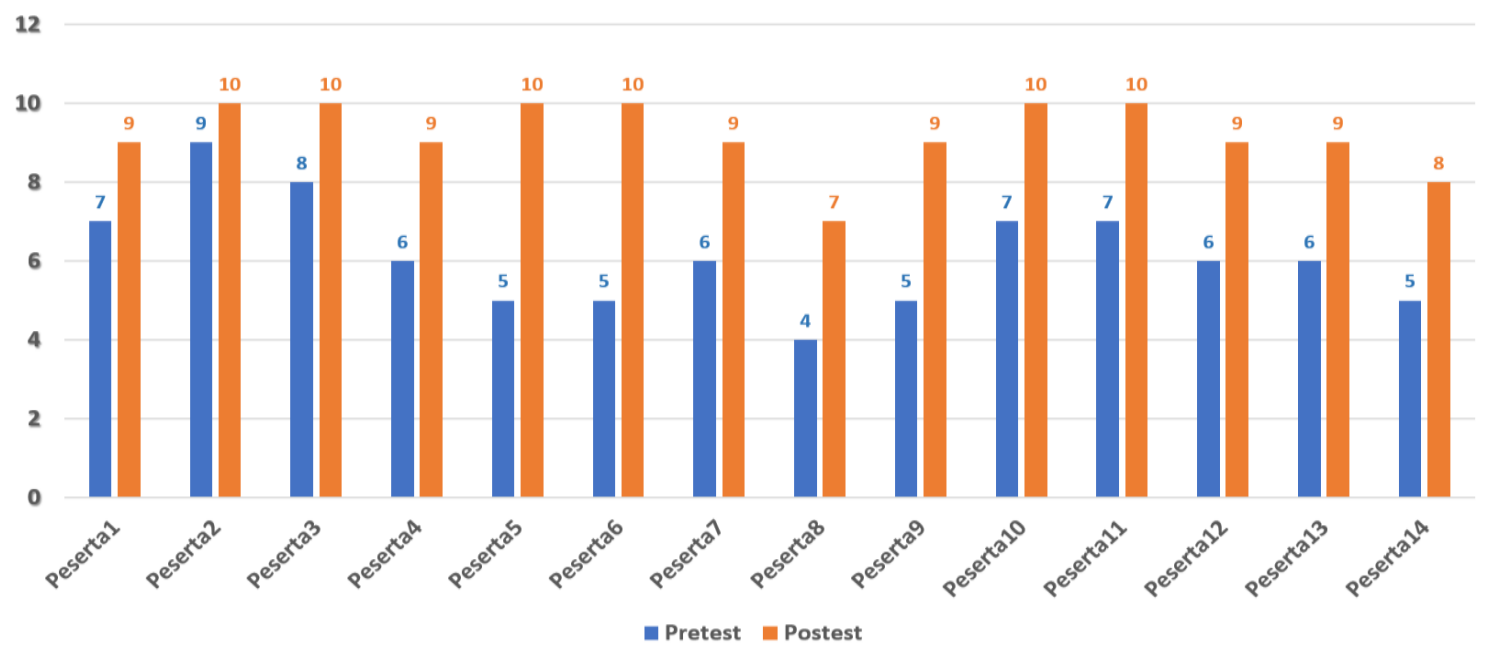

Data from pre-test and post-test results were analyzed by calculating the acquisition of a score that was categorized as normal (N-gain). The results of the Ngain descriptive analysis before and after the use of the mobile application found that the participants of the Qibla Direction learning training with computational thinking skills obtained a minimum N-Gain value of 0.50 and a maximum of 1.0 with the "Medium" and "High" Criteria. The average N-Gain value of all participants reached 0.82 and was included in the "high" category. The level of effectiveness is in the "Very Effective" category with a standard deviation of 0.17 . The graph of increasing learning outcomes is in the following: 
Figure 3. N-Gain Value on Pre-test and Post-test Results

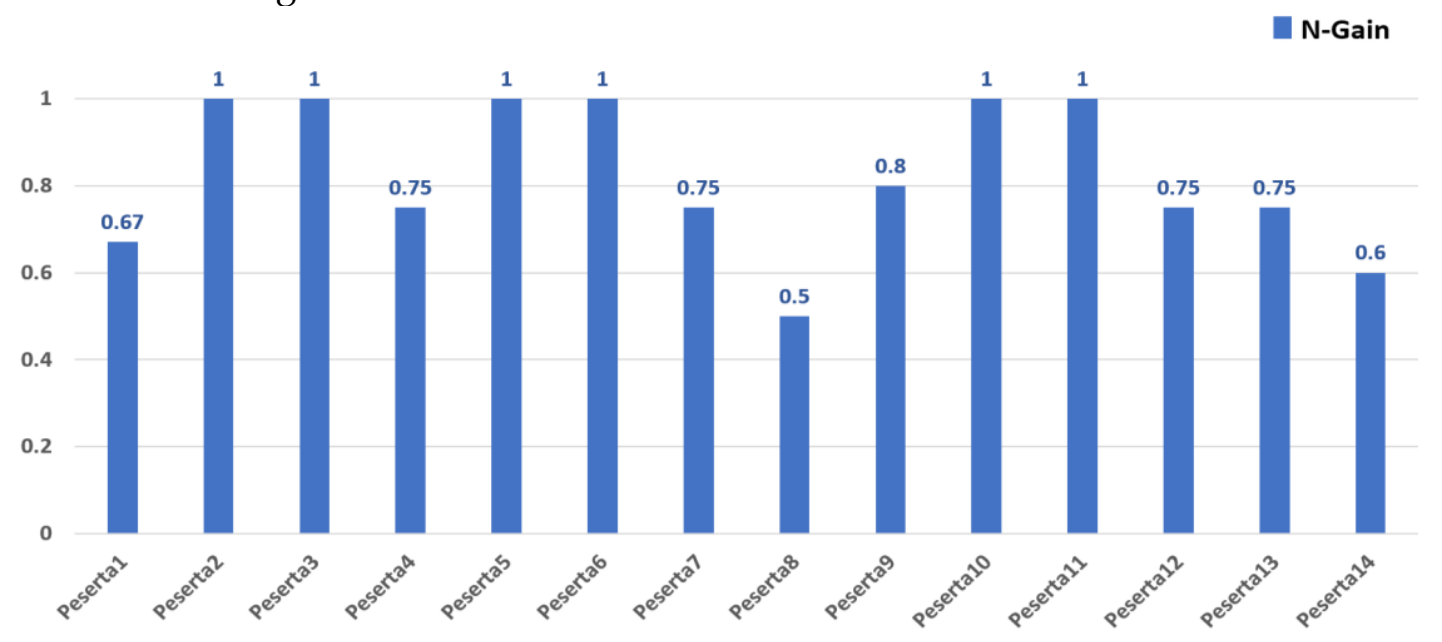

Inferential analysis was performed by $\mathrm{t}$-test. The $\mathrm{t}$ test result at alpha 0.05 shows the $t$ value is greater than the $t$ table value $(10.72>2.16)$, this indicates that $H 0$ is rejected, so it means that there is a significant increase in the results of Qibla direction learning training with mobile-based application that adapts computational thinking skills.

The main finding of this research is the obtaining of development results specifically aimed at facilitating training participants in the Ministry of Religion of the Thousand Islands in understanding concepts and mastering Qibla direction measurement skills that adapt computational thinking skills in the learning process, supported by the presence of mobile-based learning applications to improve the abilities of training participants. Referring to the results of the LPPM Uhamka team for the Community Service and Empowerment program for the Batang Regency, Central Java for 3 (three) months (April-June 2017) in the form of training in calculating the direction of qibla on one output target, which is at least $70 \%$ ( 35 people from 50 person) training participants are able to calculate the direction of the qibla and practice the measurement by practicing the WinHisab software which is the standard of the Ministry of Religion of the Republic of Indonesia (Iman, Tricahyono, \& Mariza, 2018).

Then the results of this study can be complementary in meeting the target achievement of the Qibla direction training participants. The development of this learning innovation with mobile application that was carried out is not just completing the process of calculating Qibla direction cases but was specially developed so that it is suitable for application in the developed training, thus helping trainees understand the concept of determining the Qibla direction with a structured informatics mindset, which could spur problem solving skills quickly, accurately and precisely, while increasing self-confidence in facing problems measuring Qibla direction that can arise at any time. Findings 4 Steps of Computational Thinking skills in the original qibla direction training learning process from this study, namely adapting Decomposing, Abstraction, Pattern Recognition and Algorithms thinking with new terms, namely:

1) Elaboration, steps to map the position of the area to be measured the resultant direction,

2) Determination, the step to determine the position of the coordinates of the location to be measured the result, 
3) Calculation, steps to perform calculations and determine the resulting direction;

4) Evaluation, Steps to check the results of the calculation and the suitability of the Qibla measurement results;

The results or outputs of the Qibla direction training activities that have been carried out in the Thousand Islands have not achieved the expected results (More than $70 \%$ of participants have successfully mastered the training material), often even under $50 \%$ of participants who have succeeded in understanding the concept of Qibla direction, in fact have not been able to practice precise and correct qibla direction measurement. As the results of the training in Batang, Central Java, out of 50 training participants, only 35 were able to do calculations and practice measuring qibla direction; and at least $60 \%$ (30 out of 50 people) training participants are able to calculate the start time of prayer by practicing the WinHisab software which is the standard of the Ministry of Religion of the Republic of Indonesia (Iman, Tricahyono, \& Mariza, 2018). These conditions prompted us to carry out Qibla direction learning innovations that facilitate understanding the concept and practice of measuring the Qibla direction. Other finding also stated that Android-based mobile learning media are feasible to be used as a learning resource for students (Amirullah \& Hardinata, 2017). The results of computational thinking research prove that the training participants have succeeded in understanding and being able to try to apply computational thinking in problem solving. By applying the computational thinking method in solving problems, it is found that the results obtained are more optimal. (Wibawa, Saputra, Sasongko, Adhy, \& Rismiyati, 2020) The implementation of this Qibla direction learning innovation by developing computational thinking which links it with TPACK (technology pedagogical technology content knowledge) so that it becomes a strategy and problem-solving method that can improve the quality of teaching (Maharani, 2020).

The implications of learning the Qibla direction training applied in this study can increase the sensitivity of the training participants to the role and use of information technology that guides structured thinking, thus spurring the problemsolving ability of measuring the Qibla direction quickly and precisely, while increasing their performance and productivity in a measured and directed manner in facing Qibla direction measurement problem situation with real case examples that can come at any time from the community.

The contribution of the implementation of mobile-based applications in R \& D for local ministry of religion employees is that they can function as learning assistants both physically and virtually. The use mobile-based application in learning for training could stimulate creativity, critical thinking, communicative and collaborative training participants. Mobile-based App that have been developed can certainly be accessed anytime-anywhere, so that trainees can learn independently according to their respective needs.

\section{CONCLUSION}

Obstacles in improving the quality of Qibla direction services in the work area of the Ministry of Religion Office of the Thousand Islands Regency can be overcome by training employees who use mobile-based applications so that learning materials can be accessed online anytime and anywhere with learning patterns that adapt computational thinking skills. Access to the developed application makes mobile phones a multipurpose tool in optimally supporting the implementation of Qibla direction measurement services for the community. This mobile application that has 
been developed is not only useful as a learning tool but also suitable for use in the practice of measuring the Qibla direction in various locations in the Thousand Islands region. Although at the beginning of the training, not many participants realized that their smartphone was actually equipped with a coordinate sensor, the direction of the eye with a digital compass. This training has implications in increasing the awareness of training participants of the completeness and sensors on Android phones so that they can be maximized for the benefit of public service performance, especially the direction of the Qibla in the Ministry of Religion of the Thousand Islands Regency.

Although the existence of a mobile-based application can cut the length of time the process of implementing the Qibla direction measurement service is implemented, access to this application depends on the availability of the internet network. Thus the development of mobile applications is expected to provide an incentive for the emergence of other innovative ideas to overcome various problems faced in the world of work, especially public services in the technical field of Islamic religion in the Indonesian archipelago.

\section{ACKNOWLEDGEMENT}

The author were sincere appreciation to H. Purwanto, SE, MM as head of Islamic Religious Affairs at the Provincial Office of the Ministry of Religion of DKI Jakarta, and H. Abdul Hakim, Head of Section of the Islamic Community Guidance in the Ministry of Religion of Thousand Islands Regency and also to H. Harijanto as the Board of the North Jakarta City Mosque Council of Indonesia, for their help in collecting data in the Thousand Islands region, DKI Jakarta Province, Indonesia. Thank you for the collaboration of the research team who conducted an innovative training on mobile-based Qibla guidance services.

\section{AUTHOR CONTRIBUTION STATEMENT}

The author had participated in the research and approved the final version of the manuscript.

\section{REFERENCES}

Abdullah, W. (2018). Model Blended Learning dalam Meningkatkan Efektifitas Pembelajaran. Fikrotuna, 7(1), 855-866. https://doi.org/10.32806/jf.v7i1.3169

Amirullah, G., \& Hardinata, R. (2017). Pengembangan Mobile Learning Bagi Pembelajaran. JKKP (Jurnal Kesejahteraan Keluarga Dan Pendidikan), 4(02), 97-101. https://doi.org/10.21009/jkkp.042.07

Angko, N. and M. (2013). Pretest Posttest Group. Kwangsan, 1(1), 1-15.

Anistyasari, Y., Ekohariadi, \& Munoto. (2019). Strategi pembelajaran untuk meningkatkan keterampilan pemrograman dan berpikir komputasi: sebuah studi literatur. Journal of Vocational and Technical Education, 02, 37-44.

Barr, D., Harrison, J., \& Conery, L. (2011). Computational Thinking: A Digital Age Skill for Everyone. Learning and Leading with Technology, 38(6), 20-23. Google Scholar

Cahdriyana, R. A., \& Richardo, R. (2020). Berpikir Komputasi Dalam Pembelajaran Matematika. LITERASI (Jurnal Ilmu Pendidikan), 11(1), 50. https://doi.org/10.21927/literasi.2020.11(1).50-56

Duch, W. (2007). What is computational intelligence and where is it going? Studies in Computational Intelligence, 63(June), 1-13. https://doi.org/10.1007/978-3-54071984-7_1 
Endah, S. N., Sarwoko, E. A., Bahtiar, N., Wibowo, A., \& Kurniawan, K. (2020). Pembinaan Pola Pikir Komputasi dan Informatika pada Siswa Sekolah Dasar. EDimas: Jurnal Pengabdian Kepada Masyarakat, 11(1), 1. https:// doi.org/10.26877/edimas.v11i1.2317

Fajri, Muhammad., Yurniawati., Utomo, E. (2019). Computational Thinking, Mathematical Thinking Berorientasi Gaya Kognitif Pada Pembelajaran Matematika Di Sekolah Dasar. Dinamika Matematika Sekolah Dasar 1 (1), 1-18, 1(1), 1-18. https:// doi.org/doi.org/10.21009/DSD.XXX.

Iman, M., Tricahyono, T., \& Mariza, F. (2018). Pelatihan Perhitungan Arah Qiblat dan Awal Waktu Shalat Sesuai Standar Kementerian Agama Republik Indonesia di Kabupaten Batang Jawa Tengah. Jurnal SOLMA, 7(1), 33. https://doi.org/10.29405/ solma.v7i1.658

Kawuri, K. R., Budiharti, R., \& Fauzi, A. (2019). Penerapan Computational Thinking untuk Meningkatkan Kemampuan Berpikir Kritis Siswa Kelas X MIA 9 SMA Negeri 1 Surakarta pada Materi Usaha dan Energi 6. Jurnal Materi Dan Pembelajaran Fisika (JMPF), 9(2), 116-121. Retrieved from https://jurnal.uns.ac.id/jmpf/article/view/38623

Koehler, M. J., \& Mishra, P. (2006). Technological Pedagogical Content Knowledge: A Framework for Teacher Knowledge PUNYA MISHRA. Teachers College Record, 108(6), 1017-1054. Google Scholar

Kong, S., Abelson, H., \& Lai, M. (2019). Computational Thinking Education. Computational Thinking Education. Springer Singapore. https:/ / doi.org/10.1007/978-981-13-65287

Maharani, A. (2020). Computational Thinking dalam Pembelajaran Matematika Menghadapi Era Society 5.0. Euclid, 7(2), 86. https:// doi.org/10.33603/e.v7i2.3364

Mata, P., Sistem, P., Instalasi, D. A. N., \& Udara, T. (2019). Desain Dan Pembuatan Media Pembelajaran Mobile Learning Pada Mata Pelajaran Sistem Dan Instalasi Tata Udara. Journal of Mechanical Engineering Education, 6(1), 71-79. https://doi.org/10.17509/jmee.v6i1.18245

Mulyadi, A. (2013). Akurasi arah kiblat masjid-masjid di kabupaten pamekasan 1. Nuansa, 10(1), 71-100.

Quddus, A. (2020). Implementasi Technological Pedagogical Content Knowledge (TPACK) dalam Pendidikan Profesi Guru (PPG) PAI LPTK UIN Mataram. Jurnal Tatsqif, 17(2), 213-230. https:/ / doi.org/10.20414/jtq.v17i2.1911

Rahmadi, I. F. (2019). Technological Pedagogical Content Knowledge (TPACK): Kerangka Pengetahuan Guru Abad 21. Jurnal Pendidikan Kewarganegaraan, 6(1), 65. https://doi.org/10.32493/jpkn.v6i1.y2019.p65-74

Sanford, J. F., \& Naidu, J. T. (2016). Computational Thinking Concepts for Grade School. Contemporary Issues in Education Research (CIER), 9(1), 23-32. https://doi.org/10.19030/cier.v9i1.9547

Santoso, H. A., \& Surabaya, U. N. (2020). Analisis kemampuan berpikir komputasional siswa sma, (March). https:/ / doi.org/10.13140/RG.2.2.18900.55684

Sari, I. W., \& Sumuslistiana, S. (2018). Aplikasi Mobile Learning Berbasis Android sebagai Media Pembelajaran pada Materi Program Linear Kelas XI di SMA Widya Dharma Surabaya. MUST: Journal of Mathematics Education, Science and Technology, 3(2), 175. https:// doi.org/10.30651/must.v3i2.2000

Sari, M. (2019). Analisis Model-model Blended Learning di Lembaga Pendidikan. NATURAL SCIENCE: Jurnal Pendidikan IPA Dan Pendidikan IPA, 5(2), 835-847. 
Solikin, A. (2017). Pengenalan Pengukuran Arah Kiblat di Tingkat Madrasah Ibtidaiyah/Sekolah Dasar Melalui Mata Pelajaran Matematika Materi Pengukuran Sudut. ELFALAKY: Jurnal Ilmu Falak, 1(1), 73-81.

Sukamto, T. S., Pertiwi, A., Affandy, A., Syukur, A., Hafidhoh, N., \& Hidayat, E. Y. (2019). Pengenalan Computational Thinking Sebagai Metode Problem Solving Kepada Guru dan Siswa Sekolah di Kota Semarang. Abdimasku: Jurnal Pengabdian Masyarakat, 2(2), 99. https:// doi.org/10.33633/ja.v2i2.51

Suktiningsih, W., Supatmiwati, D., Gusti, N., \& Dasriani, A. (2021). Pengenalan Pemikiran Computational Thinking untuk Guru MI dan MTs Pesantren Nurul Islam Sekarbela, 2(1), 91-102.

Suyamto, J., Masykuri, M., \& Sarwanto, S. (2020). Analisis Kemampuan Tpack (Technolgical, Pedagogical, and Content, Knowledge) Guru Biologi Sma Dalam Menyusun Perangkat Pembelajaran Materi Sistem Peredaran Darah. INKUIRI: Jurnal Pendidikan IPA, 9(1), 46. https:// doi.org/10.20961/inkuiri.v9i1.41381

Tamhane, K., Khan, W. T., Tribhuwan, S. R., Burke, A. P., \& Take, S. B. (2015). Mobile Learning Application. International Journal of Scientific and Research Publications, 5(1), 22503153.

Tegeh, I. M., \& Kirna, I. M. (2013). Pengembangan Bahan Ajar Metode Penelitian Pendidikan dengan ADDIE Model. Jurnal Pendidikan, 11(1), 16.

Ulum, M., Islam, U., \& Kiblat, A. (2020). Pelatihan Penentuan dan Pendampingan Pembenahan Arah Kiblat Masjid di Kecamatan Tambaksari Kota Surabaya. Nusantara Journal of Community Engagement, 1(1), 22-28. Google Scholar

Wibawa, H. A., Saputra, R., Sasongko, P. S., Adhy, S., \& Rismiyati, R. (2020). Pelatihan Computational Thinking bagi Guru SMP-SMK Muhammadiyah 2 Kota Semarang. E-Dimas: Jurnal Pengabdian Kepada Masyarakat, 11(2), 173-178. https:/ / doi.org/10.26877/e-dimas.v11i2.3041

Wijayanto, R., \& Santoso, R. H. (2017). Pengembangan Bahan Ajar Matematika Dengan Pendekatan Problem Solving Berorientasi Pada Kemampuan Pemecahan Masalah. Journal of Education, 1(1), 4.

\section{Copyright Holder :}

(C) Fathurahman, F., (2021).

First Publication Right :

(C) Jurnal Iqra' : Kajian Ilmu Pendidikan

This article is under:

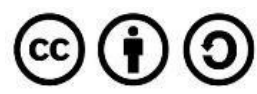

